\title{
The return of what never left: animals present in future natures
}

\author{
Guilherme José da Silva e Sá \\ Departamento de Antropologia, Universidade de Brasília, Brasília, DF, Brasil
}

\begin{abstract}
This article presents data collected in ethnographic research begun in 2014 at the Faia Brava Reserve in Portugal. The Faia Brava Reserve has been dedicated to ecological restoration by the association that manages it. This has made the reserve the starting point of an ambitious project for re-naturalizing the western region of the Iberian Peninsula, which foresees the reintroduction of large animal species in Portugal through its integration to the Rewilding Europe network. The article describes some of the steps necessary to the creation of re-naturalization areas, and some of the hypotheses associated to the re-naturalization project in Europe and particularly in Portugal.
\end{abstract}

Keywords: Re-naturalization; Rewilding Europe; Portugal; Faia Brava; Fauna reinsertion.

\section{A volta do que não foi: sobre animais presentes em naturezas futuras}

\section{Resumo}

Neste artigo apresento dados coletados em pesquisa etnográfica iniciada no ano de 2014 na Reserva da Faia Brava (Portugal). A Reserva da Faia Brava possui uma característica que tem sido fomentada pela associação que a administra que é destinar-se ao restauro ecológico. Essa especificidade fez da Reserva o ponto de partida para um ambicioso projeto de renaturalização da região oeste da península ibérica, que prevê a reintrodução de espécies animais de grande porte em território português através de sua integração à rede Rewilding Europe. Ao longo do texto descreverei algumas das etapas necessárias à criação de áreas de renaturalização, bem como, levantarei algumas hipóteses vinculadas ao projeto de renaturalização da Europa, e particularmente de Portugal.

Palavras-chave: renaturalização; Rewilding Europe; Portugal; Faia Brava; refaunação. 


\section{The return of what never left:}

\section{animals present in future natures}

\section{Guilherme José da Silva e Sá}

This article presents data collected during ethnographic research initiated in 2014 at the Faia Brava Reserve, which is considered by Portugal's Institute for Nature Conservation and Forests (ICNF)' as the first private protected district of Portugal. The specific purpose of the Faia Brava Reserve is ecological restoration, which is promoted and administered by the Transhumance and Nature Association (ATN). This specificity made the Reserve the starting point of an ambitious project to re-naturalize ${ }^{2}$ the western region of the Iberian Peninsula, which foresees the reintroduction of large animal species in Portuguese territory through its integration to the Rewilding Europe network. In this article I will describe some of the steps needed for the creation of re-naturalization areas, and some hypotheses will be proposed regarding Europe's re-naturalization project, and especially Portugal's.

\section{An ethnographic introduction to the field of research}

I woke early to go to the Lisbon bus station to take a bus to Guarda, the city where I would rent a car to reach the village of Figueira de Castelo Rodrigo. The trip to the city of Guarda ${ }^{3}$ took about five hours, and I spent the last one admiring Portugal's highest mountain range, the Serra da Estrela. On my walk to the car rental agency, I came across a public market that smelled of the old butcher shops and artisan cheeses, as well as some "Chinese stores". ${ }^{4}$ There was a Brazilian working at one of them, who still spoke with an accent from the interior of São Paulo State, although he was living there for 14 years. I had a bite at a 24-hour convenience store in a gas station where I bought a local weekly newspaper called "Terras da Beira" [Lands at the Edge]. The news in the 28 August 2014 issue was particularly interesting because it provided clues to what lay before me. The main headline reported "Figueira de Castelo Rodrigo joins the 'New Populators' program and Seia also shows interest in joining". "New Populators" was the name given to the rural re-population program that offers assistance to the implementation or transfer of businesses to the Portuguese countryside. It was created in 2007 after a conversation among neighbors, a sociologist, and a technician in a local development association. The project involves registering "new settler" families for their later placement on lands compatible with their vocations. Thus, the concession given to each family also depends on the identification, made by a technical team, of the business potential in each region. In the case of Figueira de Castelo Rodrigo the plan is to settle five families to fulfill an immediate need for people willing to raise livestock and work in granite production.

The re-population of territory shared the front page space with the article "Forest Fires in the District: Less area burned than last year". The wildfires that spread through the region in late summer are facilitated by high temperatures, low rainfall and winds that constantly change direction. The firefighters are forced to divide into various work fronts to cover the large area with rocky terrain and ground vegetation.

\footnotetext{
1 The Portuguese government entity responsible for the conservation of nature and biodiversity.

2 The term "re-naturalization" has been used by conservation biologists to refer to a deliberate process of reintroducing animal and vegetable species to recover a degraded ecosystem.

3 Guarda is one of the main cities located in Portugal's Beira Interior Norte region.

4 Where a variety of things are sold, from domestic utensils to stationary and clothing.
} 
Although the news reported an annual reduction in the extent of land burned, the next day the television news reported a proliferation of fires. I was told later that forest fires are one of the main concerns of the administrators of the Faia Brava Reserve. To prevent them, the perimeter is monitored daily to identify possible outbreaks that could threaten the reserve. On the first days of my study I accompanied a night inspection tour, and we observed a large arc of fire spread by the wind over a region close to the Côa River Valley.

The issue of burning land was recurring when we discussed the memories and motivations of the work of the general manager of the Transhumance and Nature Association and the Coordinator in Portugal of the Rewilding Europe initiative. But for now, a brief news item mentioned in a weekly column of the newspaper should be mentioned: "The National Republican Guard identifies arson suspect fire in the Corujeira area". The fire that destroyed approximately 60 to 80 hectares in the Serra da Estrela Natural Park had been caused, according to a source from the Territorial Unit of the National Guard5, by a man seeking revenge against his siblings over a family inheritance" since the fire began next to the suspect's home "and everything around was burned, except for his property" (Terras da Beira newspaper, 08/22/2014). The news events seem to be deeply connected to people's lives in that region. If on one hand there is space for family revenge that marks the soil of the region with burning rage, on the other, it is also reported that the “"Solidarity Blanket Campaign Exceeds Expectations" (Terras da Beira, 22/08/2014).The personal nature of the news seems to indicate the inseparable presence of people at each location, on each path, on each stone wall that after centuries, combine with the natural landscapes. Life here is conspicuous.

The same issue of the weekly paper had a column entitled "Men \& Wolves: A summer tale", signed by the Wolf Group of the Animal Biology Department of the College of Science at the University of Lisbon. The story was about Mondego, a shepherd dog that would accompany a cow herd all alone:

He just stays there, on guard even when lying down; observing the dozen cows that went up the hill with him and that would soon go back down: his family. At least the only one Mondego knows; He has no memory of his true origin, the siblings from his liter. In the vast space where the herd wanders and grazes he found his home, his freedom and his mission.

Years later, Mondego's owner would not tire of telling the story of what happened that night, told with fanciful traces, but faithful to what really happened:

when the cows went downhill, I noticed that a calf was missing. And Mondego had also stayed behind on the hill. But there was a heavy fog and I had to wait until morning to go after them. When I came across the calf, it was lying down by some rocks, to take shelter... with the dog leaning on him, as if they were two dogs. Mondego didn't want to leave the little one alone and spent the whole night watching over him. And I don't know if he had to defend him against a wolf.

The text finishes the heroic narrative:

The one thing we know is that the story really happened, in our fields. And if our hero was a Catro Laboreiro or a Serra da Estrela ${ }^{6}$ dog, or any other, its not important. Because that is the life of many sheep dogs that accompany 'their' cows, goats and sheep each day, risking their lives in face of the wolf - but also of the men, always ungrateful, with their traps, their cars and their poisons (Terras da Beira, August $24^{\text {th }}, 2014$ ).

5 National Republican Guard. 
This is a story of adaptations and compositions like everything in life in this region. Instead of celebrating nature that preserves rigid borders, a discourse is found about a "re-nature" that survives through its compositions. Family is that to which an individual adapts to once adopted. Dogs and cattle are no longer distinguished and become antagonists of equally adapted enemies, the wolf and man. Against the first one - its agility and pack -the dog's size advantage (historically modeled by human hands in the creation of shepherd breeds). It is also necessary to re-equip the canine anatomy, placing heavy collars with pointy nails on the dogs to protect against wolf bites. Against the "man", in a Hobbesian recombinant inversion, the wolf becomes the man of the wolf. The return of the great predator to the European fields attributes a new meaning to old practices. The wolf reinvents the dog, which recreates the grazing, which is hoped will give new meaning to life in the countryside and to people's lives. Therefore, only by renouncing their old and (new) traps, can human beings rebuild this cycle. Instead of understanding a tacit opposition between human activities - like transhumance and regulated hunting - and the elements that are part of "nature" (fauna and flora), what is expected is a conviviality accord. In this agreement to a mutual reinvention of "nature" and of human practices, resides the hope in a future that, if on one hand, evokes a mythical past, on the other is guided by new terms capable of preventing the predatory actions of the past. In this manner, with news about the detention of two men for "hunting crimes" - one of them was hunting without either a firearms' license or a hunter's license, and the other was hunting non-authorized species the issue of the local newspaper is closed, but this is only one more beginning.

\section{The research}

The central objective of the study that I have been conducting since 2014 is to accompany the implementation of a new kind of nature preserve, and the practices of the various agents involved. The "rewilding" guidelines and their use to implement natural parks are recent in the history of conservation biology, less than a decade old. Thus, it was found that one of the peculiarities of this sort of re-naturalization program is its inextricable connection to proposals for human activities guided by an idea of a sustainable economic development. To the degree that they are opposed to the argument of preserving an "original state of nature", environmentalists that support re-naturalization affirm that - just as we customarily associate the notion of production to culture - nature should and can be re-composed through processes regarded as artificial. From this it can be inferred that a wide range of possibilities for interaction among human and non-human species becomes possible the moment that the belief in a non-anthropic nature, is renounced.

I will begin with a story of an encounter that sought to identify new possible areas for the expansion of the re-naturalization project. The event narrated, which took place after three years of the "Rewilding Europe" project in the region of Beira Alta Interior in Portugal, marked the beginning of a new stage of the re-naturalization project in the western portion of the Iberian Peninsula. At that moment, after having established the experiment at the Faia Brava Reserve, ${ }^{7}$ planning began to extend its scope along the Côa River Valley.

7 Private reserve for nature conservation, with 850 hectares, located between the counties of Pinhel and Figueira de Castelo Rodrigo (Portugal). It was founded in 2003 and is managed by the Transhumance and Nature Association. In 2011 it became part of the Rewilding Europe network, and is one of the model re-naturalization sites in Europe. 


\section{First act: in search of the void, defining the course}

We met at around nine in the morning at an intersection in a small village along a highway. The group, now formed by two anthropologists (myself and an intern from the reserve), two biologists who worked at the Faia Brava reserve and two directors of the Rewilding Europe organization, took a 4-wheel drive vehicle along a tortuous road that soon became a narrow track of dirt and rocks. After a steep ascent, we got out and continued on foot to the top of a hill where we could see the landscape for miles around. We stood on a gigantic granite block, with one hand holding binoculars and the other pointing to the horizon, as if our fingertips could frame the terrain.

The deep silence in that bucolic landscape was only interrupted by the enthusiastic conversations and the hurried steps of the visitors. After being surprised that a Brazilian anthropologist had learned about the Rewilding Europe initiative, one of the directors began his explanation, careful to be as didactic as possible in the presentation of the aims of that field visit to Portugal. At one side of the valley it was possible to find cultivated regions with approximately " 40 to $60 \%$ of human occupation", on the opposite hillside could be seen granite formations that the director enthusiastically indicated as being "the future of the Rewilding project in Portugal". He patiently explained that the aim of the Rewilding Europe initiative was to act in regions where human presence was scarce. Speaking of the next stage of Portugal's re-naturalization project, percentages were used once again, to explain it would be implemented in territories that were "80 to $100 \%$ abandoned". According to the director, those demographic voids presented good conditions for nature to be reconstructed, and as it would be later said, in the future they could represent a "good opportunity" for people to inhabit the region.

Wandering along a trail that crossed villages of just a few dozen inhabitants - mostly inhabited by elderly people - the plans for the next years of the Rewilding project began to take shape. The trails led us to sites of stonewall ruins - traces of centuries-old human occupation that combined with the originally rocky terrain, creating a green-gray mosaic of symmetrical and asymmetrical shapes. There were also remains of old windmills and irrigation canals, elements of a system that made viable the harvest of vegetables by drawing water from the creek that ran nearby. The director frequently stopped and expressed his view about the future landscape of these places. There would be young people hiking and cyclists mountain biking along the valley trails. In the surrounding area there would be herds of wild horses and cattle, with mountain goats balancing on the cliffs. Eagles and vultures would paint the sky. The focus on a viable future, as we shall see, is the main differential of the Rewilding Europe initiative in relation to other homonym rewilding projects already in progress. While some proposals for re-naturalization projects call for a return to a state of nature based on the past - as suggested by the "Rewilding to Pleistocene" project in the United States - Rewilding Europe concentrates on creating future environments of interaction between humans and the natural environment. Within this logic, the questioning about what would be the optimal point to be reached in re-naturalization is not in fact relevant. Re-naturalization, according to Rewilding Europe's orientation, is primarily about what "nature" could become rather than what it was one day.

\section{The genesis of the rewilding concept}

Coined originally in the United States in the years 2000, the term rewilding ${ }^{8}$ was related to the idea of fomenting the elaboration of an alternative model for wildlife conservation reserves in North America. Also known as "Rewilding to Pleistocene" this proposal - postulated by a group of renowned specialists of conservation ecology - sought to stipulate concrete bases for the reintroduction of animal species

8 The term "rewilding" refers to a process of "re-wilding" ou "re-naturalization", I chose to preserve the idea of "re-naturalization" in this text because it highlights the strong element of artificialization involved in the construction of environments involved. 
(above all, herbivores representative of mega fauna and large predators) in areas that they did not inhabit at the time. Inasmuch as they evoked a past time, the reference to the Pleistocene was an allusion to the environmental conditions found in the beginning of human occupation and expansion on the planet. Although they acknowledged the difficulty in "bringing back to life" animal species already extinct for millenniums, the mentors of this kind of "re-naturalization" presented in two articles that had large repercussion in academic and environmentalist circles, what they considered to be the concrete foundations for the recovering of the degraded ecosystems.

The first of their principles pondered that human beings had the moral authority - and even the ethical duty - to intervene in the natural environment, since their irresponsible actions had directly or indirectly caused the extinction of several other animals and vegetables species. Even so, according to Donlan et al. (2005), human beings will continue to cause extinctions, to modify ecosystems and to alter the course of evolution, which makes taking a political position to reach a solution, without denying participation in the problem, highly desirable.

This perception seems to place the problem in a much broader arena of contemporary discussion, that of discourses about the imminence of a new geologic "era", widely known as the "Anthropocene". ${ }^{9}$ This is the moment or event in which the role of the human species is affirmed as a new and constant force of intervention in the planet's bio-physical processes.

"However much we would wish otherwise, humans will continue to cause extinctions, change ecosystems and alter the course of evolution. (...) Our proposal is based on several observations. First, Earth is nowhere pristine; our economics, politics, demographics and technology pervade every ecosystem. (...) humans were probably at least partly responsible for the Late Pleistocene extinctions in North America, and our subsequent activities have curtailed the evolutionary potential of most remaining large vertebrates. We therefore bear an ethical responsibility to redress these problems." (Donlan et al. 2005: 436).

"Far more than any other species in the history of life on Earth, humans alter their environments by eliminating species and changing ecosystem function (...). Earth is now nowhere pristine, in the sense of being substantially free from human influence, and indeed, most major land masses have sustained many thousands of years of human occupancy and impacts (...). Human-induced environmental impacts are now unprecedented in their magnitude and cosmopolitan in their distribution, and they show alarming signs of worsening. (Donlan et al. 2006: 660-1).

In a certain sense, the "naturalization" of the human presence and agency gives the rewilding conservation mode unique characteristics, because it attributes to humans a protagonism in the task of returning to the Earth its old ecosystems. To do so it is necessary to intervene proactively in its dynamics and vital processes. Consequently, it is possible to infer that the notion of an untouched nature becomes detached from the vocabulary of those who promote a re-naturalization strategy. Nature, therefore, would maintain a great potential for artificialization to the degree that it is no longer possible to speak of the existence of isolated species, but of a range of relations integrated to actions of these species (which inevitably would include humans).

After overcoming the initial obstacle sustained by the myth of untouched nature, it is necessary to take the next steps that aim to restore the functional "health" of the ecosystems, and to do so it is indispensable to adopt a proactive posture or, as they prefer to say, an "optimistic" perspective for twenty-first century conservationism. Several possibilities for reconstructing certain ecosystems have been carefully studied, identifying their functional processes of interaction and their trophic chains, to evaluate the viability

9 "But we have already seen how the definition of the Anthropocene consists in the phenomenon of the collapse of the scalar magnitude. When the biological species-agent becomes a geophysical species-force (through the historical mediation of species-engineering), when the political economy encounters cosmic entropy, it is the ideas of scale and dimension that seem to be out of scale" (Danowski \& Viveiros de Castro 2014: 128). 
of species reintroduction. That is, if it would be possible to relocate individuals from other areas or if it would be necessary to consider the use of "proxy" species that would fulfill the functional role played by those that are now extinct. Thus, the pursuit is not only to return independent species, but to emphasize the re-composition of functional interactions among them and fundamentally their food chains. This disposition leads to the understanding that it would be necessary to prioritize the reintroduction of large predators and or large herbivores, because this would assure the recovery of the entire trophic chain - from top to bottom - given that the investment in the reintroduction of a top-of-the-chain predator would require conditions suitable to its nutrition and survival. Nevertheless, the reasons emphasized for the choice of large animals transcends organicist explanations, even though they still maintain a certain pragmatism. According to the creators of the rewilding proposal, the animals representative of mega fauna are clearly those endowed with greater charisma, which would more easily mobilize interest, resources, and empathy among humans. This is a fundamental point that is considered in any re-naturalization project. Having the support of public opinion is vital for the equation that relates sustainability and fund raising. In addition, the proven adhesion of environmental recovery to a scenario of sustainable economic environment becomes an outstanding strategy of persuasion regarding the viability and "rationality" of the project, which at first sight may not seem to be very reasonable.

\section{Rewilding Europe}

Although the proposal formulated by Donlan et al. $(2005,2006)$ became a global reference for the term rewilding, it is far from being the only possible definition. Projects inspired by re-naturalization are in progress in different parts of the world, with technical and ideological specificities. For example, the idea of a return to the Pleistocene is shared by U.S. and Russian initiatives, but does not really represent the interests of the Rewilding Europe network, which focuses on what the ecological niches could become in the future. The Rewilding Europe initiative also differs in terms of the viability and reality of its implementation. While the projects to return to the Pleistocene seem to exist only as bold projections, Rewilding Europe's work has been underway since 2011.

With its headquarters in Nijmegen, Holland, the Rewilding Europe organization is a network involving large and small conservationist NGOs, investors and banks that support local projects, researchers linked to universities that provide the technical foundations for implementing the planned actions, rural land owners and farmers, as well as tourists and volunteers that circulate in the eight (soon expected to be ten) model rewilding areas in Europe.

In the activities promoted by Rewilding Europe, the concept of "re-naturalization" assumes a particular character, that sees in the generation of social and economic opportunities a way to return wildlife to Europe and vice-verse. Therefore, it concerns committing to the planning of a future nature without exactly perpetuating the old ties inherited from natural history. Through the re-appropriation and re-occupation of land abandoned in the historical process of rural exodus in 2oth century Europe, re-naturalization consists of an ecologically viable model for areas considered economically unproductive.

The effect generated by this intervention is the creation of private reserves in areas that are progressively purchased with funds from small and large investors' who, in turn, become partners of the re-naturalization project. The reserves, in general, are managed by local non-governmental organizations, which represent a broad range of stakeholders. There are other ways to become part of a rewilding project, such as, leasing land to manage re-introduced natural resources (animal species in general) or by establishing partnerships to offer services related to Eco-tourism (primarily the creation of rural hotels and small restaurants). 
However, the scope of the model-areas of re-naturalization related to the Rewilding Europe initiative does not always coincide with the limits of those private reserves, and often transcends them. This occurs due to the fact that the areas occupied by animals may exceed park borders. The re-naturalization areas are conceived as large territorial extensions which must serve the survival of the animal and vegetable species (re-introduced and/or recovered through management plans). The fact that many of these animals are migratory and therefore cannot be restricted to the reserves causes a re-naturalization area to be understood as the area occupied by the species. The reserves themselves function as future hot spots from where the animals could migrate by defining routes and ecological corridors that, with some human investment, would integrate the entire system.

To the degree that the rewilding areas in Europe are defined by the vital flows of the animals, they are also marked by their long history of anthropization. This element is regularly considered in the action plans of Rewilding Europe. At the same time as the zones are prepared to receive the projects for animal reintroduction, the conditions needed to ensure visits of tourists and researchers interested in wildlife are also developed. An example of an investment dedicated to this type of visitor is the building of shelters inside the reserves, where it is possible to observe and photograph animals with the full discretion needed for this purpose. In addition, an effort is made for the commercial activities destined to tourism in the region around the protected areas to be improved through training courses in rural hotel management, the food industry and sales of traditional regional products.

Concerning the reintroduction of species, there is some consensus among the ecologists involved with the Rewilding Europe, who understand the management of a reserve similar to that of a rural property. Wolves, bears, lynxes, horses, cattle and goats in a wild state, besides eagles and vultures, are some of the animal species envisioned in the re-population project for the future European nature. Avoiding as much as possible the introduction of exogenous species, the effort is focused on recovering native species - even making use of genetic studies and of direct intervention in the environment when creating sanctuaries and food zones for the animal populations - with the aim of returning them to the remodeled landscape according to interests that combine environmentalism with sustainable economic development. To achieve those ends, there are a few restrictions to human intervention in processes regarded as being "natural". It is common to hear that, in areas historically abandoned by human occupation, "nature returns" progressively to regain its space. Typically, this is the process that has been observed in some regions of Europe in recent decades. However, it is known that the time of autonomous re-composition of these flows is reasonably long and for this reason it is beneficial for humans to give an "initial boost" to the process. Nevertheless, the artificialization of nature is seen as a trigger and not as a substitute for non-human agencies that gradually tend towards autonomy.

\section{Second act: a good deal, strengthening the strategy}

After defining the new program for re-naturalization in Portugal based on the exploratory incursions to the field during the technical visit by the Rewilding Europe team, it became necessary to implement the strategy. To do so, some procedures and measures have been taken.

First, the maps and property deeds were reviewed to precisely identify the overlapping of the areas within the scope of the rewilding progression. Concurrently, meetings with representatives of local councils and entities were scheduled to inform them about the initiative underway. I attended one of these events at the City Council Chamber in Beira Alta Interior. The presentation was made by the local coordinator of Rewilding Europe who reviewed all the advantages in the project, that involved the re-valuation of territory long abandoned because soil depletion left it no longer fruitful for conventional agriculture (planting and 
grazing). This re-adjustment would involve a shift of economic activities from agriculture to eco-tourism. Since it was plausible to imagine that the replacement of one activity for another could result in an even greater depopulation of the region, the coordinator explained that investing in nature could be a "good business" that would even allow resuming some traditional activities (such as the artisan production of sweets, cheeses, olive oil, jams, and various utensils) to sell to tourists.

The coordinator began explaining the partnership system offered by the rewilding initiative, which called for access to financing to adjust herds (replacing horse and cattle breeds considered exogenous for breeds of interest to reintroduction), ${ }^{10}$ for land leasing, and for small businesses related to the rewilding. The development of a network of services such as operators of outdoor activities, photographic safaris, hotel businesses and traditional rural food services converge on that considered the motto of Rewilding Europe: providing an "experience with wildlife" in European territory.

After quietly listening to the explanation, the Council Chamber representative asked what in fact was being asked of them. The coordinator replied that at the time he only wanted to inform them about Rewilding Europe's work in the region and wanted to count on the help of public representatives to promote the project. The request was accepted.

Rewilding Europe's strategy of action then went to a new stage of persuasion and search for local supporters to expand the re-naturalization area. To do so, in the months following the exploratory survey, contacts were made with public and community representatives who could be mediators between the organization and possible partners.

\section{Rewilding Europe in Portugal}

Originally, the area destined to the re-naturalization of the western region of the Iberian Peninsula would be related to conservation initiatives in Portugal and Spain. The territory from northeastern Portugal - in the Guarda region - to the west of Spain - in the Castilla y Leon region - have at their extremes the Faiva Brava Reserve in Portugal and Campanarios de Azaba Reserve in Spain. This transborder region has common historical and geographical elements and a past of agricultural activities that have slowly lost relevance and interest among new generations of inhabitants. This caused a progressive decline in villages of the region and some have been totally abandoned. Due to the migration of young people to urban centers such as Lisbon, Porto, Salamanca and Madrid, and even to other countries, the local population got older and has struggled to maintain their pastues and limited food production.

After the first three years of action in the region, an evaluation of the results was conducted so that in 2014 it would be possible to begin a new phase of the re-naturalization project in western Iberia. While the Portuguese initiative was highly praised for reaching the goals within the deadlines, the activities in Spain did not achieve the desired results and the partnership with Rewilding Europe was canceled. This forced a rethinking of the organization's strategy for the following years, and the visit of the central staff of Rewilding Europe to Portugal served to explore new zones to expand the renaturalization project, which with the Spanish partners' withdrawal, would take a new direction from the Faia Brava Reserve. Incursions now led to the Côa River, a region with a low population density and few agricultural and pasture activities, and which, in compensation, is has a terrain of rocky cliffs and crystalline waters. 


\section{Some issues re-naturalization raises for Anthropology}

The transition from the $20^{\text {th }}$ to the $21^{\text {st }}$ century marked an ambiguous panorama for natural history. On one hand it intensified the degradation of ecosystems and the consequent threat to survival of several animals and vegetables species, especially in the regions between the tropics. On the other, considerable advances were made in environmental legislation in the northern hemisphere and in mobilizing public opinion about the need for an integrated ecological project for the planet.

The rise of this ecological thinking took place in light of the evident loss of vast areas of native forest and the depletion of cultivable regions, in particular in Europe. This contingency guided two measures - with opposite moral senses - in face of the decline of European agricultural production. The first exaggerated the exploratory character of agricultural production redirecting and creating new transnational commercial agreements with emerging economies from the southern hemisphere. This global expansion of agriculture was also responsible for the spread of deforestation problems on a global scale, aggravated by weak local environmental laws. The ecological crisis was no longer an easily located issue and became more systemic, with global effects and causes over history.

The European rural exodus and devaluation of part of the traditionally cultivated lands also led to what Bernardina (2011) called a 'post-rural society', which is basically the resumption of a lifestyle determined by a certain "rurality" combined with the interest of providing real conditions for reviving local economies through rural and ecological tourism. This latter dimension relates to recognizing practices of rural life as heritage, including local techniques, hunting, manufacturing, festivals, commensality, cooperation, etc., and the creation of natural parks through reforestation and reintroduction of animals.

Both strategies aim to generate capital (though they diverge about the focus), either through the action of large multinational companies in Africa or Latin America, or through that of small businesses of residents in rural European regions. Such duplicity - which is not redundant - helps us to understand the original contexts of the programs approached in this article. The rewilding projects are strongly guided by the motivational principles that steer a capitalist system. From the mobilization of resources, to the way they communicate their proposals and the liberal administration of nature policies cause these projects to be seen as an idyllic revival of capitalism. However, a new configuration of the production chain is presented, since nature is not seen simply as a supplier of raw material, but also as the product to be sold after certain transformations. We must thus consider how the environmental business of re-naturalizing - which purports to be proactive in the reconstruction of natural spaces vital to human beings and nonhumans - can be considered at the heart of what is called the "Anthropocene" (or "Capitalocene") (Hache 2014). Anthropocene, is a term that was coined by biologist Eugene Stroemer and made popular since the 1980 s by renowned chemist Paul Crutzen who defends its use: "It seems appropriate to apply the term 'Anthropocene' to the present days, a geological age which is dominated by human kind in many different ways." (Crutzend apud Kolbert 2015).

Thus, the geologic age that we officially live in, the Holocene, would give place to a new context characterized by the advent of human action as a geological force, which has been able to decisively interfere in processes said to be "natural" on the planet. The re-appropriation of the concept in the denomination "Capitalocene" seeks to call attention to the fact that this peculiarly destructive agency of human beings towards the planet is not an intrinsic characteristic of our species, but rather its complicity with a certain form of appropriation of the world: capitalism. The term Capitalocene is supported by the sociologist Jason Moore's (2014) perspective, for whom, according to Danowski \& Viveiros de Castro (2014), "The Industrial Revolution that began in the early nineteenth century is just a consequence of 
the socioeconomic mutation that generated capitalism in the "long sixteenth century", and therefore, the source of the crises is, ultimately, in the production relations, more than (and before than) in the productive forces, if we can explain it like this." (2014: 28)

At a first moment, what can be considered locally, based on preliminary ethnographic data, recognizes an apparent shift in the logic of the anthropocene - which is usually associated with the cataclysmic and destructive effects of human action on nature - in relation to forms of human intervention that intend, to the contrary, to reconstruct nature. But what can sound like an altruistic manifestation of what is called "Green Capitalism", can also reveal in certain cases, such as the Breakthrough Institute, a megalomaniac and technophile presumption.

Certain close relatives close of the Singularitarian people, nevertheless, have dedicated some attention to the problem, inquiring into the immediate technological conditions for the survival of capitalism and its main conquests, liberty and security, in a situation of growing energy consumption and persistent dependence on fossil fuels. The Breakthrough Institute, a think tank from North America (California, in fact), whose exact position on the political spectrum is hard to pinpoint, is perhaps the most visible name among the advocates of a green capitalism that puts its faith on centralized solutions that would be capable of implementing ambitious techno-engineering projects on behalf of big capital, with high material investment, and organically (if that is the right word) embedded in Big Science: hydraulic fracking of rock to obtain fossil fuel, expanding and perfecting nuclear power stations, large hydroelectric projects (like the dams in the Amazon Basin), generalizing the monoculture of genetically modified vegetables, environmental geo-engineering and so on. (Danowski \& Viveiros de Castro 2014: 66-7).

If both motivations - negative and positive - seem to come from the same capitalist source, to the degree that this source causes the destruction of ecosystems, they also re-adapt it, presenting themselves as a means to its reconstruction. As Stengers states: "It is the nature of capitalism to explore opportunities, it cannot avoid this. The logic of capitalist actions cannot avoid identifying the intrusion of Gaia with the appearance of a new field of opportunities." (Stengers 2015:47).

I understand, however, that the magnitude of the rewilding dream is on a utopian scale much smaller than that planned by the Singularitarians represented by the Breakthrough Institute. Although the model of environmental recuperation and management presented by Rewilding Europe intends to reorganize productive activities based on a sense of opportunity, according to which investing in nature can be a good business, there is no idealization that cutting-edge technology and large scale projects may substitute the local - and deeply human - responsibility of "boosting" processes considered to be vital.

In this manner, it is essential to ask exactly what issues the rewilding initiatives are able to raise for the discussion about the Anthropocene? To what degree do they dialogue with other initiatives of a collectivist proposal that in this context are gaining strength?

\section{Implications of the reconstruction of a natural heritage}

By considering some issues from the world scenario - where the Rewilding Europe is located - and about the Anthropocene, the greatest contribution we can make to this topic is to describe ethnographically the actions taken locally in partnership with the re-naturalization project in Portugal. This leads us to a second dimension of this study that focuses on the processes of recognizing heritage implicit to re-naturalization programs. As previously mentioned in debates regarding the concept of cultural heritage, the recognition of nature as heritage in a rewilding context, no longer follows the standard parameters of inviolability and "authenticity" attributed to a specific natural landscape. Re-naturalization theorists say that the 
artificialization necessary to reconstruct these environments is part of the strategy for the preservation of species and their respective ecosystems. That is, if the criteria of "authenticity" and contiguity with the past can be reevaluated regarding the certification of certain cultural heritages, according to Gonçalves (1996), the same can be said about a natural heritage deliberately reconstituted by human agency. In the latter case, it would be necessary not to focus on an analysis of the species that inhabit a certain biome, but on the interactions of the species that would allow reproducing the functional role that each species performed. For defenders of re-naturalization, while the contours of a species may disappear, the traces of their interactions remain.

"Such benchmarks would be defined not only by the presence or absence of species, but also by the presence or absence of species interactions - the true functional fabric of nature (Estes, 2002)." (Donlan et al. 2006: 661)

“(...) the focus of conservation biology is expanding to include not only species but species interactions (Soulé et al. 2003, 2005).” (Donlan et al. 2006).

In practice, the level of intervention in the landscape through the reintroduction of animals and plants is regulated by the evaluation and the technical capacity to enact these measures. The project involves frequent consultations with ecologists specialized in the reintroduction of animals in wild environments because, besides their expertise, it is necessary to have great knowledge of the veterinary, sanitary and legal aspects in each country. Only by considering these norms is it possible to undertake and manage a species reintroduction project. In this context, there are partnerships between organizations that foster re-naturalization and public and private institutions (universities, research centers, regulatory agencies) to which the consultants of the reintroduction processes are associated. These professionals, besides giving information about the ecology of species in focus, have broad knowledge about the possible problems of the introduction of a specific animal or plant. Therefore, it is necessary that the choice of the species to be reintroduced suits the various dimensions of its future existence, such as potential conflict with the human population, the trophic and territorial sustainability, hunting laws, reproductive cycles and even the effective aesthetic sought in relation to public opinion.

This relationship with the local inhabitants is of vital importance for the execution of the rewilding project. Not only adults are regularly seen as possible partners. The new generations of children are considered ideal mediators in the proposal to revalue the natural landscape. As a way to reach children and youth, the rewilding team makes regular visits to schools. They give talks on social-environmental education and promote native seedlings "adoption" programs for later planting in reforestation zones, including Faia Brava.

This fact leads us to the issue of how the rewilding initiatives are locally implemented. It calls attention to the inclusive aspect of the human presence since the beginning of the development of the activities in the reserves. If anthropization is not an epistemological problem, it is also not a practical barrier for the re-naturalization actions. The consolidation of this model for natural reserves foresees the continuous mobilization of associations and local inhabitants who will coexist with large predators such as wolves, Iberian lynxes, birds of prey, horses, cattle, as well as shepherds, small farmers and at times hunters (whose actions are regulated by government agencies).

However, there is a controversy between the artificiality and authenticity in the way these natural parks are idealized. New natural landscapes arise as the environments are recomposed where the human and non-human elements responsible for the good functioning of their operating chains are present. Thus, if elements that in the past ensured the subsistence of families - such as the unchecked extraction and exploitation of natural resources - can no longer exist, they must be substituted by new options for 
interaction that shall have a similar role. In this context, new stimuli such as family hotels and country cooking associated to the farms are considered to be sustainable forms propitious to the re-establishment of the ties between humans and nature.

The relation between the intention to evoke an image that reflects the old-fashioned lifestyle (land management, hunting, rusticity) and the need to adapt to contemporary conditions associated to outdoor experiences (preservationism, animal rights, photographic safaris, new communication technologies etc.) produce an opposition between the idealization and realization of the project. One example is the way the population traditionally established its ties with the natural landscape in opposition to the expectation generated by the new projects to commercialize this lifestyle. It is possible to infer that a sort of landscape transfiguration has always been carried out by the villagers, as they brought home elements of the wildlife surrounding them (hunting trophies, amulets, decorations, healing substances etc.). Nevertheless, the model of rural tourism currently proposed imposes on the population the need to open their sphere of private life to visitors. Far from undergoing this inversion unscathed, when they appropriate nature - that had always been "outside" - the villagers do not do so without abandoning a certain lifestyle that made possible the transfiguration of the natural landscape in the domestic sphere. Modern life demands that those people re-think, for example, the place of their hunting trophies (taxidermy displays) that decorate their fireplaces and walls, and come to identify new natural and living trophies in the environment outside their homes. Shifting from hunting to photographic safaris is, therefore, a great behavioral change, which deeply reflects on local modes of existence.

References to the past are always conditioned to their roles as idyllic guiders of that which might be done in the future, and never as impediments to what should be done. It is in this fact that resides one of the main (self)definitions of the "re-naturalization" initiative: to promote an "optimistic" and "positive" ecology. The perception of the role of human beings as proactive agents in the process of recovering the environment - which had been destroyed by previous human agency - makes these projects a privileged locus for anthropological analysis that understands nature as a human co-production. Perhaps a good example of this, is found at the Faia Brava Reserve. At the moment of its acquisition, ruins of old abandoned pigeon coops were found near the Reserve. Those constructions, very common in that region of Portugal had a dual function in the past: producing animal excrement to fertilize the poor soil for farming and providing a meat supply (of pigeons) for the people who lived in the region especially at times when food was scarce. After creating the reserve, the pigeon coops were remodeled and their functionality was partially recovered, which is increasing the population of pigeons that in turn are prey for eagles threatened with extinction that live in the rocky cliffs near the Côa River. The incorporation of those coops into the landscape of the nature reserve also justifies the function of these artifacts within the chain of interactions in a rewilding project. Something similar took place with the planting of vegetables at the reserve so they would serve as a food supply for rabbits, which are food for eagles, foxes and, opportunely by lynxes.

That "return" of animal species, either re-introduced or through population recovery, brings a consequent resignification of animals and of the environment itself, as seen in the recent return of Iberian wolves to the region. The return of this large predator was possible due to multiple factors, such as its easy adaptation and locomotion, the national policy to protect the Iberian wolf, and the demographic voids which provided the gradual regeneration of the forests, creating ecological niches that function as a refuge and become part of the wolves territory. However, the presence of wolves became a serious problem for farmers, whose livestock is attacked and who allege that their losses are not fairly compensated by the state. The presence of wolves, which is noticed by identifying their tracks, although they are rarely seen, has already been associated to the rewilding environmentalists. In this manner, new myths appear locally, like the one that states that wolves have been re-introduced in the region at night by helicopter. Evidently, 
due to the potential conflict presented by the presence of wolves, the species has never been considered as a candidate for reintroduction. However, considering the rejection of the wolf, the problem becomes resignified by the defenders of re-naturalization who observe that the reintroduction of herbivore species would attenuate the shepherds losses, given that the predatory attacks on livestock would be redirected to wild fauna.

It is possible to conclude that the reconstruction of natural environments takes place by evoking ancestral modes of survival and landscapes, even if on canvases painted by human hands. Therefore, the reintroduction of animals that disappeared long ago is connected to the recovery of myths, narratives and images articulated in an anthropic environment.

Moreover, the reintroduction of the concept of nature as an important category in the social sciences takes place at a good moment. Without recurring to eco-materialist traditions that have permeated anthropological theory since the second half of the twentieth century we now observe the reinvention of nature as a concept that should adjust to innovations in the ethnographic fields. By appropriating the spirit of rewilding, we enter a period in which the culture of creativity allow us to imagine possible futures for anthropology.

Translated by Ivy de Siqueira

Revised by Jeffrey Hoff

Received: January 20, 2016; Approved: August 19, 2016

\section{References}

BERNARDINA, Sergio Dalla. 2011. Le retour du prédateur: mises en scène du sauvage dans la société post-rurale.

Rennes: Presses Universitaires des Rennes..

BONNEUIL, Christophe; FRESSOZ, Jean-Baptiste. 2013. L'événement anthropocene. Paris: Éditions du Seuil.

DANOWSKI, Déborah; VIVEIROS DE CASTRO, Eduardo. 2014. Há mundo por vir? Ensaio sobre os medos e os fins.

Florianópolis: Cultura e Barbárie.

DESCOLA, Philippe. 2005. Par-delà nature et culture. Paris: Éditions Gallimard. . 2011. L'ecologie des autres. L'anthropologie et la question de la nature. Paris: Editions Quae.

DONLAN, Josh et al. 2005. "Re-wilding North America". Nature, 436: 913-914. 2006. "Pleistocene rewilding: an optimistic agenda for twenty-first century conservation". The

American Naturalist, 168(5): 66o-681.

GONÇALVES, José Reginaldo Santos. 1996. “A obsessão pela cultura”. In: Cultura no plural. Rio de Janeiro: CCBB.

HACHE, Émilie (org.). 2014. De L’univers clos au monde infini. France: Éditions Dehors.

KOLBERT, Elizabeth. 2015. A sexta extinção: uma história não natural. Rio de Janeiro: Intrínseca.

MOORE, Jason W. 2014. “The Capitalocene”. In: http://www.jasonwmoore.com/Essays.html.

STENGERS, Isabelle. 2015. No tempo das catástrofes. São Paulo: Cosac Naify.

\section{Guilherme José da Silva e Sá}

Professor in the Anthropology Department, University of Brasília, Coordinator of the Anthropology

of Science and Technology Laboratory, Brasília, DF, Brazil.

E-mail: guilherme_jose_sa@yahoo.com.br 